\title{
Purification of Iron Oxide Obtained from Iron Precipitation of the Zinc Leaching Residues
}

Production of purified hematite from iron ores by $\mathrm{Na}_{2} \mathrm{~B}_{4} \mathrm{O}_{7}$ flux fusion method-I -

by Takaho OOTOMO ${ }^{1}$ and Noboru TAGUCHI ${ }^{1}$

1. Mining College, Akita University, Tegata, Akita 010

Purification of iron oxide obtained from Iron Precipitation of the Zinc leaching residues with $\mathrm{Na}_{2} \mathrm{~B}_{4} \mathrm{O}_{7}$ flux have been investigated by use of the recrystallization method.

And, the effects of retention time at $1,200^{\circ} \mathrm{C}$, cooling rate, iron oxide/flux ratio, $\mathrm{CuO}$ and $\mathrm{NaF}$ additions on size, purity and the yield of hematite crystal were tested.

The main results obtained are as follows:

(1) The size of hematite crystals decreased with the increasing cooling rate from $1^{\circ} \mathrm{C} / \mathrm{min}$ to $10^{\circ} \mathrm{C} / \mathrm{min}$.

(2) The purity of hematite crystals was about $>99.8 \%$ of $\mathrm{Fe}_{2} \mathrm{O}_{3}$, and the contents of $\mathrm{Zn}, \mathrm{S}$, As were $130 \sim$ $300 \mathrm{ppm}, 7 \sim 20 \mathrm{ppm}$ and about $30 \mathrm{ppm}$, respectively.

(3) The yield of hematite crystals increased up to $>80 \%$ with increasing cooling rate and the iron oxide/flux ratio and with an increase of $\mathrm{NaF}$ addition.

KEY WORDS: Iron Oxides, $\mathrm{Na}_{2} \mathrm{~B}_{4} \mathrm{O}_{7}$ Flux, Crystallization, Purification

\section{1. 緒論}

通常, 磁性材料などに用いられるへマタイトは蓚酸, 水酸化鉄 の加熱分解，硫化鉄の酸化ばい焼によって製造されている1）。

しかし製造法によって得られる酸化鉄のキャラクタリゼーショ ンは微妙に異なる ${ }^{2)}$ 。そのため次工程で造られる磁性材料の品質 に悪影響を及ぼすことが知られ，一層の高純度化法が望まれる。 と同時に, 将来の需要増加が見込まれることから, その量産が重 要と思われる。

一方, 高純度へマタイト単結晶や粉の製造には $\mathrm{Na}_{2} \mathrm{O}-\mathrm{B}_{2} \mathrm{O}_{3}$ 系 フラックスによる浸出法 ${ }^{3)}$ や溶融再結晶法 ${ }^{3) 4}$ が報告されている。

前者の方法は原料酸化鉄とほう砂の混合粉を $850^{\circ} \mathrm{C} て ゙ 5 \mathrm{~h}$ 加熱処 理し, 原料酸化鉄の不純物をフラックス中に溶解させ, その後温 水, 塩酸あるいは硝酸水溶液で洗浄して不純物を除去する方法で ある。しかしこの場合, 原料の表面に遊離している不純物はフラ ックスに溶解するが, 試料内部に存在する不純物は溶解しないで 残るため, 不純物の除去効率が悪く, また洗浄に時間が多く必要 とするなどの欠点がある。後者の方法は原料酸化鉄とほう砂の混 合粉を $1,200{ }^{\circ} \mathrm{C}$ 以上の温度で加熱溶融し, 所定の冷却速度で㠜固 させ，温硝酸溶液による溶解処理によって，可溶のフラックス部

* 1991 年 1 月 16 日受付 8 月 12 日受理 資源 ·素材学会平成元 2 年東北支部秋季大会にて発表

1. 正会員 秋田大学助手 鉱山学部資源 ·素材工学科

2. 正会員 工博 秋田大学教授 鉱山学部資源 - 素材工学科

キーワード: 酸化鉄, ほう酸フラックス, 晶出, 高純度化
と晶出した不溶のへマタイト結晶をろ過分離できる, 簡易で比較 的時間の短い処理法である。

本研究は, 低品位各種鉄鉱石から高純度へマタイトの製造と量 産を図る研究の一環として, まず带鉛浸出残渣の脱鉄処理（へマ タイト法) で生じる酸化鉄 (以後残渣酸化鉄と略す) を原料とす ることを検討した。この残渣酸化鉄は $\mathrm{Zn}, \mathrm{S}, \mathrm{As}$ などが多く含ま れるため販路対策に困笨しているもので, 高純度へマタイト原料 として使用できれば資源有効利用として大いに意味がある。ここ では高純度化法として溶融再結晶法をとりあげ, 高純度化と収 率に及ぼすフラックスと残椬酸化鉄の混合量比, フラックスの組 成, 加熱冷却条件, 凝固時のへマタイトの核生成および成長を促 進する添加剤の使压などの基礎的操作条件の検討を行った。

\section{2. 実 験 方 法}

Table 1 The chemical composition of hematite produced in the residue treatment process to precipitate iron (wt\%).

\begin{tabular}{l|c|c|c|c|c|c|c}
\hline $\mathrm{T} \cdot \mathrm{Fe}\left(\mathrm{Fe}_{2} \mathrm{O}_{3}\right)$ & $\mathrm{Zn}$ & $\mathrm{S}$ & $\mathrm{As}$ & $\mathrm{K}$ & $\mathrm{CaO}$ & $\mathrm{H}_{2} \mathrm{O}$ & $\mathrm{SO}_{3}$ \\
\hline $52.17(74.59)$ & 0.60 & 4.49 & 0.51 & 0.64 & 0.94 & 9.61 & 11.09 \\
\hline
\end{tabular}

Table 2 Size distribution of original hematite (wt $\%$ ).

\begin{tabular}{c|c|c|c|c|c}
\hline$+50 \mu \mathrm{m}$ & $50 \sim 30 \mu \mathrm{m}$ & $30 \sim 20 \mu \mathrm{m}$ & $20 \sim 10 \mu \mathrm{m}$ & $10 \sim 5 \mu \mathrm{m}$ & $-5 \mu \mathrm{m}$ \\
\hline 14.9 & 40.6 & 29.7 & 9.4 & 2.2 & 3.2 \\
\hline
\end{tabular}


Table 3 The constitution of samples (wt\%).

\begin{tabular}{r|c|c|c|c}
\hline Sample & Iron oxide & $\mathrm{Na}_{2} \mathrm{~B}_{4} \mathrm{O}_{7}$ & $\mathrm{CuO}$ & $\mathrm{NaF}$ \\
\hline $\mathrm{A}_{1}-1$ & 26.5 & 70.8 & 2.7 & - \\
2 & 35.0 & 62.3 & 2.7 & - \\
3 & 40.0 & 57.3 & 2.7 & - \\
4 & 45.0 & 52.3 & 2.7 & - \\
$\mathrm{A}_{2}-1$ & 27.2 & 72.8 & - & - \\
2 & 35.0 & 65.0 & - & - \\
3 & 40.0 & 60.0 & - & - \\
4 & 45.0 & 55.0 & - & - \\
$\mathrm{B}-$ & 35.0 & 60.0 & - & 5 \\
1 & 35.0 & 55.0 & - & 10 \\
2 & 35.0 & 50.0 & - & 15 \\
\hline
\end{tabular}

表 1 および表 2 はそれぞれ残渻酸化鉄の化学組成と粒度分布を 示す。不純物として,とくに S, Asが高い。供試混合試料は, 残渣 酸化鉄 $26.5 \%$ ，ほう砂 $\left(\mathrm{Na}_{2} \mathrm{~B}_{4} \mathrm{O}_{7}\right) 70.8 \%$ ，それに結品成長促進剤 のCuOを $2.7 \%$ 加えた Tasaki の基本組成 ${ }^{4)}$ と,さらに残椬酸化鉄 を $35 \%, 40 \%, 45 \%$ と变えた $\mathrm{A}_{1}$ 試料, $\mathrm{CuO}$ 無添加の組成の $\mathrm{A}_{2}$ 試料および残渣酸化鉄を $35 \%$ と固定し, $\mathrm{Na}_{2} \mathrm{~B}_{4} \mathrm{O}_{7}$ の一部を $\mathrm{NaF}$ 添加 ${ }^{4}$ で置換し, フラックスの融点降下を試みた $\mathrm{B}$ 試料であり，それぞ れの配合組成を表了に示す。この配合試料を摩碎しながら十分に 混合した試料 $0.5 \mathrm{~g}$ を酸素流通下 $(100 \mathrm{ml} / \mathrm{min})$, 図 1 に示寸操作 で，白金るつぼ中で $1,200^{\circ} \mathrm{C}$ に加熱溶融し，所定の保持時間と冷 却速度で $800{ }^{\circ} \mathrm{C}$ まで降温したのち炉冷した。保持時間は $3,20 \mathrm{~min}$, 冷却速度は $1,10{ }^{\circ} \mathrm{C} / \mathrm{min}$ と変えた。その後融解物を $10 \%$ 温硝酸溶 夜に浸漬し，フラックス部を溶かし，不溶のへマタイト結晶をろ

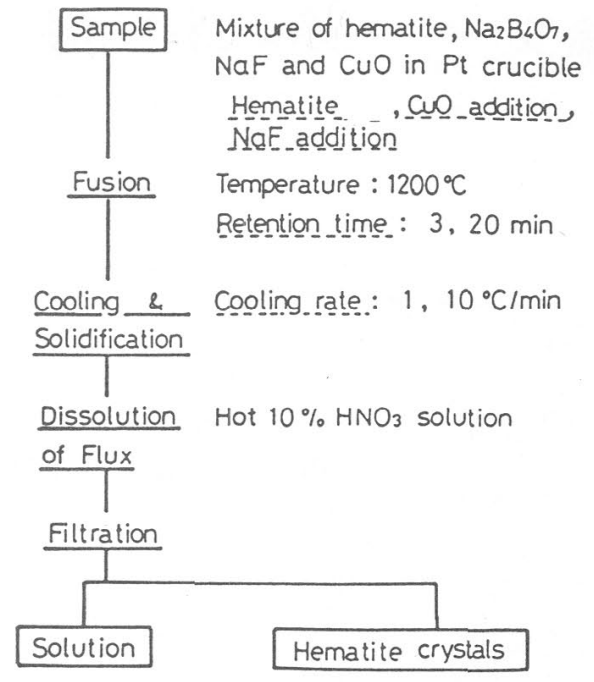

Fig. 1 Flow sheet of the experimental method.

過分離し，水洗・乾燥してへマタイト結晶を得た。へマタイト結 晶の收率はろ液中の鉄分の化学分析值から求めた。

へマタイト結晶の晶出状態は光学頙微鏡で, 表面組織観察や含 有不純元素の分析はEPMA (Electron Probe Microanalyzer) と I C P ( Inductively Coupled Plasma) を用いて行った。な お, I C Pの分析精度は $\mathrm{Cu}, \mathrm{Zn}, \mathrm{S}, \mathrm{As}$ についてそれぞれ士 5 ppm, $\pm 2 \mathrm{ppm}, \pm 0.5 \mathrm{ppm}, \pm 1$ ppmである。

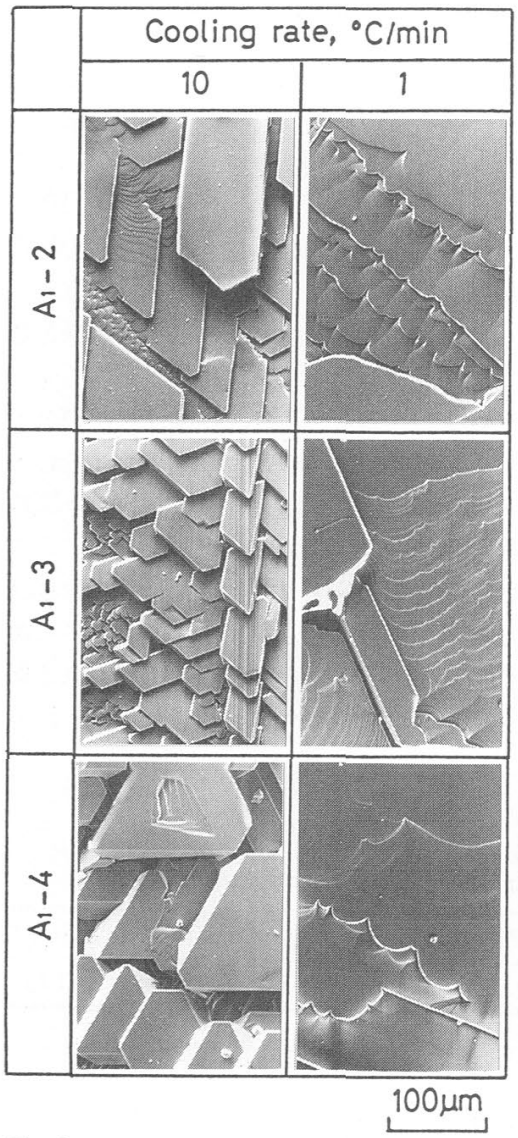

Fig. 2 Scanning electron micrographs of $\mathrm{Fe}_{2} \mathrm{O}_{3}$ crystals ( $\mathrm{A}_{1}$ - series) after the flux treatment with $\mathrm{Na}_{2} \mathrm{~B}_{4} \mathrm{O}_{7}+\mathrm{CuO}$ at $1,200^{\circ} \mathrm{C}$ for $3 \mathrm{~min}$ and the leaching treatment with hot $10 \%-\mathrm{HNO}_{3}$ solution.

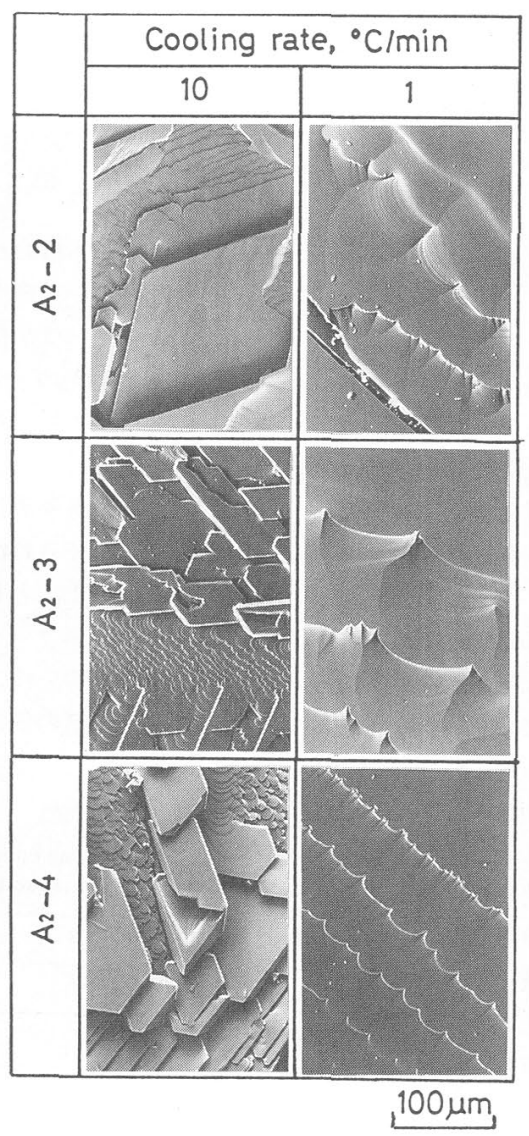

Fig. 3 Scanning electron micrographs of $\mathrm{Fe}_{2} \mathrm{O}_{3}$ crystals $\left(\mathrm{A}_{2}\right.$ - series) after the flux treatment with $\mathrm{Na}_{2} \mathrm{~B}_{4} \mathrm{O}_{7}$ at $1,200^{\circ} \mathrm{C}$ for $3 \mathrm{~min}$ and the leaching treatment with hot $10 \%-\mathrm{HNO}_{3}$ solution.

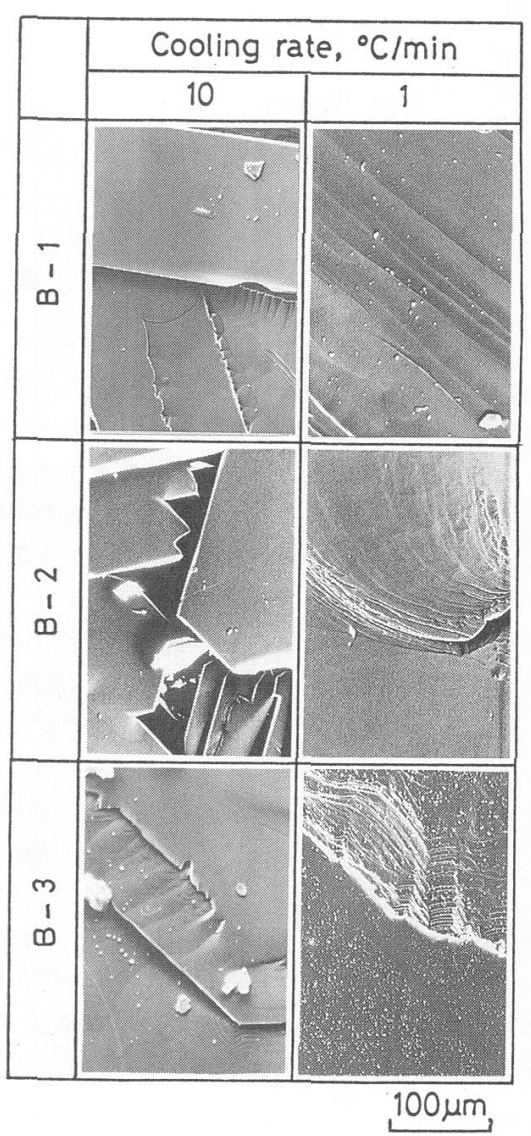

Fig. 4 Scanning electron micrographs of $\mathrm{Fe}_{2} \mathrm{O}_{3}$ crystals (B - series) after the flux treatment with $\mathrm{Na}_{2} \mathrm{~B}_{4} \mathrm{O}_{7}+\mathrm{NaF}$ at $1,200^{\circ} \mathrm{C}$ for $3 \mathrm{~min}$ and the leaching treatment with hot $10 \%-\mathrm{HNO}_{3}$ solution. 


\section{3. 結果および考察}

\section{$3 \cdot 1$ ヘマタイト結晶の形態}

融解物中のへマタイト結晶は白金るつぼ壁面から垂直に内部に 向かって針状や板状で晶出しており, その後の硝酸水溶液処理で フラックス部を溶解して, ろ過分離したへマタイト結晶は灰白色 の金属光沢を示し，その大きさは全ての実験条件の範囲内で 0.1 〜 $4 \mathrm{~mm}$ 角程度の薄片であった。そのためろ過性がよく, 水洗や 乾燥が容易であった。 $\mathrm{CuO}$ 添加 ( $\mathrm{A}_{1}$ 試料), 無添加 ( $\mathrm{A}_{2}$ 試料) お よび $\mathrm{NaF}$ 添加（B 試料）におけるへマタイト結晶の EPMAによ る二次電子像をそれぞれ図 2 , 図 3 および図 4 に示す。

組織から, $\mathrm{A}_{1}$ と $\mathrm{A}_{2}$ 試料における, 冷却速度が $10^{\circ} \mathrm{C} / \mathrm{min}$ の場合 は, へマタイト結晶表面はほぼ六角結晶板の積層を示し, また冷 却速度が $1{ }^{\circ} \mathrm{C} / \mathrm{min}$ の場合は, 結晶端が波状の結晶板の積層を示し ていることが認められる。各積層結晶は冷却速度の低下によって 大きくなり, 大きな単結晶が晶析するようになっている。また $\mathrm{B}$ 試料の場合, 結晶は $\mathrm{A}$ 試料よりさらに大きくなっている。

\section{$3 \cdot 2$ ヘマタイト結晶の純度}

図 5 はフラックスにCuOを添加した場合のへマタイト結晶中の $\mathrm{Zn}, \mathrm{S}$ の含有量に及ぼす残渣酸化鉄量, 冷却速度の影響を示す。

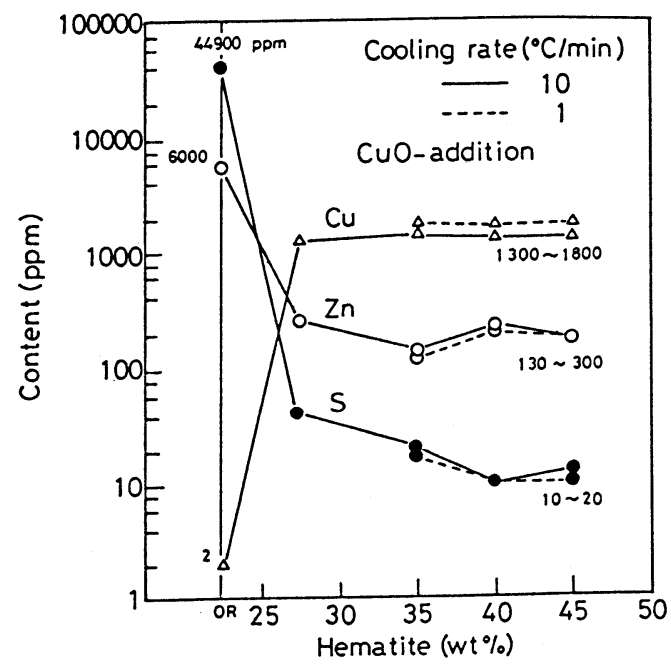

Fig. 5 Effect of the amount of hematite in samples on impurity contents of $\mathrm{Fe}_{2} \mathrm{O}_{3}$ crystal (Retention time : $3 \mathrm{~min}$ ).

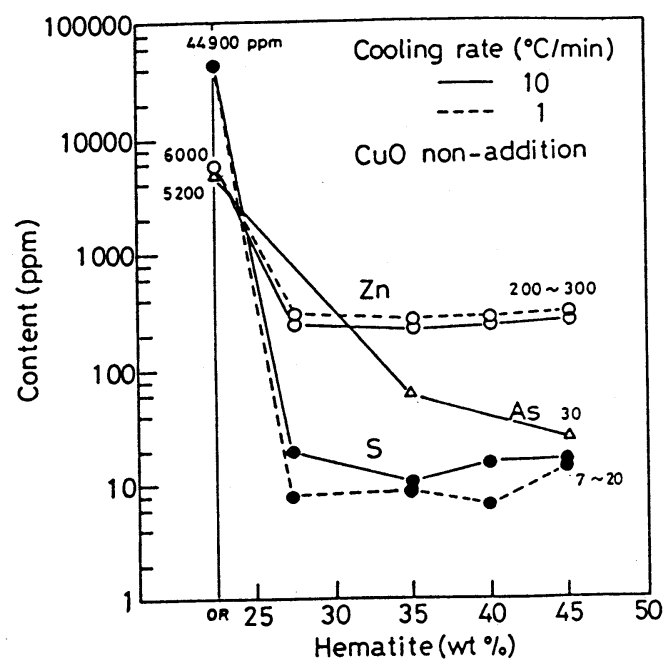

Fig. 6 Effect of the amount of hematite in samples on impurity contents of $\mathrm{Fe}_{2} \mathrm{O}_{3}$ crystal (Retention time : 3 min).

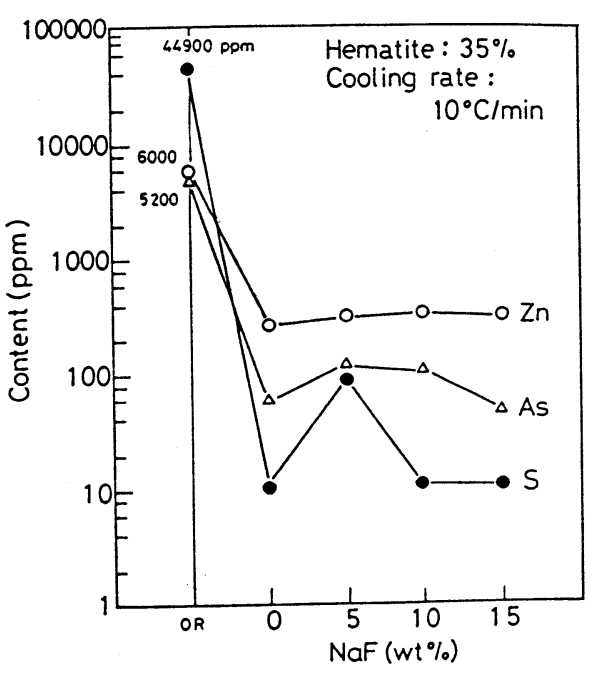

Fig. 7 Effect of NaF addition into flux on impurity contents of $\mathrm{Fe}_{2} \mathrm{O}_{3}$ crystal (Retention time : $3 \mathrm{~min}$ ).

ヘマタイト結晶中の $\mathrm{Zn}, \mathrm{S}$ の含有量は, 残椬酸化鉄量および冷 却速度に関係なく, フラックス処理によって急激に低下し, それ ぞれ130〜300 ppm, 10〜20ppm とほぼ一定の值を示している。 しかし, $\mathrm{CuO}$ の添加はCu 含有量を $1,300 \sim 1,800 \mathrm{ppm}$ と高めるの で好ましくないことがわかる。なおこの場合Asの定量は行わなか った。

図6はCuOを添加しない場合のへマタイト結晶中の $\mathrm{Zn}$, As， $\mathrm{S}$ の含有量に及ぼす残渣酸化鉄量，冷却速度の影響を示す。

ヘマタイト結晶中の $\mathrm{Zn}, \mathrm{S}$ の含有量は, 残椬酸化鉄量に関係な く, フラックス処理によって急激に低下し，それぞれ $200 \sim 300$ ppm , 7〜 $20 \mathrm{ppm}$ とほぼ一定の值を示している。しかし冷却速度 が小さいと, 僅かながら $\mathrm{Zn}$ は高く, S は低下する。As は残渣酸 化鉄量が $45 \%$ で $30 \mathrm{ppm}$ までに低下している。S と As の低下が顕 著であるのは, フラックス中の $\mathrm{Na}_{2} \mathrm{O}$ による $\mathrm{S}, \mathrm{As}$ の吸収能が高 いためと考えられる。

図 7 は, 残渣酸化鉄量を $35 \%$ および冷却速度を $10^{\circ} \mathrm{C} / \mathrm{min}$ と固 定し， $\mathrm{Na}_{2} \mathrm{~B}_{4} \mathrm{O}_{7}$ の一部を $\mathrm{NaF}$ て置き換えたときの, $\mathrm{NaF}$ 添加量が $\mathrm{Zn}, \mathrm{As}, \mathrm{S}$ 含有量に及ぼす影響を示す。 $\mathrm{NaF}$ 添加はへマタイト結 晶の高純度化という点では効果のないことを示している。

いずれにしても, フラックス溶融法によって, 残椬酸化鉄は 99.8\% 以上に高純度化できることがわかった。

\section{3・3 ヘマタイト結晶の収率}

図8 はへマタイト結晶の収率に及ぼす溶融温度における保持時 間の影響を示す。結晶の収率は保持時間を変えても変らない。

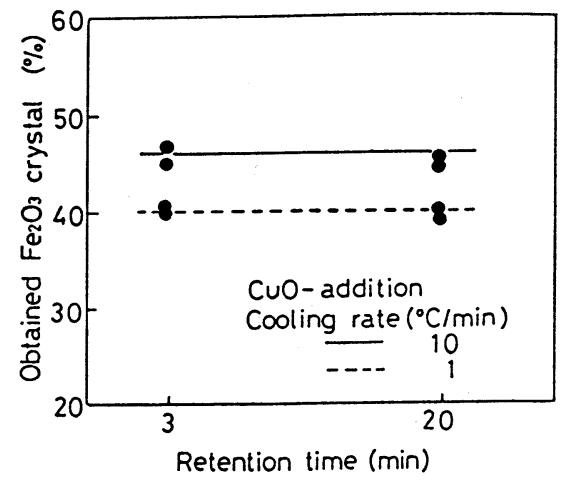

Fig. $8 \mathrm{Effect}$ of the retention time at $1,200^{\circ} \mathrm{Con}$ the yield of $\mathrm{Fe}_{2} \mathrm{O}_{3}$ crystal $\left(\mathrm{A}_{1}-1\right.$ sample). 


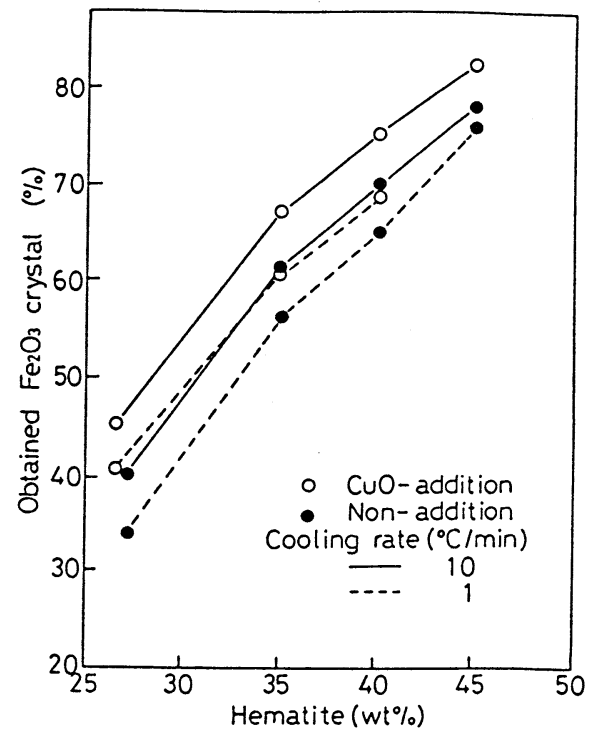

Fig. 9 Relation between the yield of $\mathrm{Fe}_{2} \mathrm{O}_{3}$ crystal (\%) and amount of hematite in samples.

このことは $1,200{ }^{\circ} \mathrm{C}$ まで昇温段階で残渣酸化鉄がフラックス に完全に溶融できれば，その後の降温におけるへマタイトの晶出 に影響を及ぼさないことを示している。

図9はへマタイト結晶の収率に及ぼす残渣酸化鉄処理量, 冷却 速度, $\mathrm{CuO}$ 添加の影響を示す。残渣酸化鉄量の増加, 冷却速度の 上昇および $\mathrm{CuO}$ 添加は結晶の収率を増す。一方, 図10から, $\mathrm{NaF}$ の15\%までの添加が無添加の場合よりへマタイト結晶の収率を17 $\%$ 程度向上させることを示している。

鉄損失の主な原因の一つは, 酸化鉄のフラックスへの溶解と温 $10 \%$ 硝酸水溶液への溶解が考えられる ${ }^{4)}$ 。しかし本実験では, 後 者は無視できるほど小さいことが認められた。一方可溶のフラッ

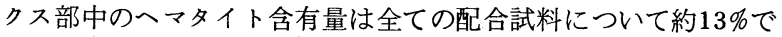
あり,これは $\mathrm{BARKS} 5^{5)}$ が求めた $\mathrm{Na}_{2} \mathrm{~B}_{4} \mathrm{O}_{7}-\mathrm{Fe}_{2} \mathrm{O}_{3}$ 系の単純共 晶型状態図の $800^{\circ} \mathrm{C}$ における液相線濃度 $12.5 \%$ とほぼ一致する。 従って, 処理温度範囲でフラックスに残渣酸化鉄を多く溶かし

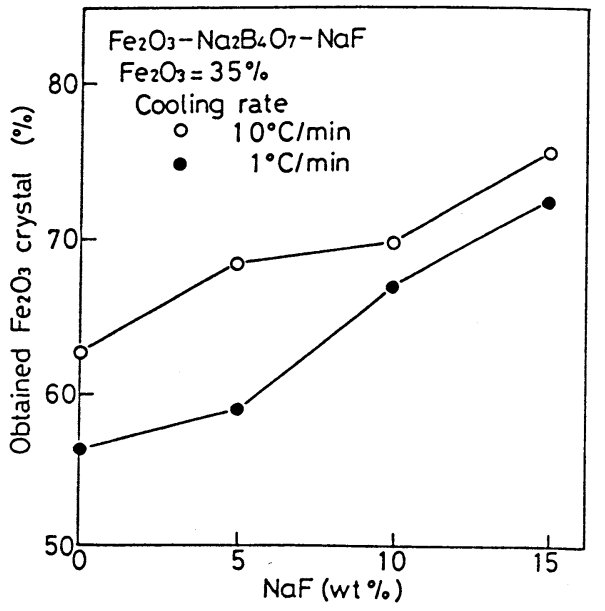

Fig. 10 Effect of $\mathrm{NaF}$ addition into flux on the yield of $\mathrm{Fe}_{2} \mathrm{O}_{3}$ crystal (wt\%).
込めばそれだけへマタイトの晶出量は増すことになり，酸化鉄の フラックスへの溶解量がへマタイトの収率を左右する要因と考え てよい。なお実験中のフラックスの蒸発量は配合割合の $2 \sim 3 \%$ 程度であることを認めた。

冷却速度とへマタイト収率との関係では, 本実験の冷却速度範 囲で, 冷却速度が大きければ収率は高くなることを示した。この ことは, 工藤ら ${ }^{3)}$ のように冷却速度が大きければ, 収率は低下す るという結果と異なっている。本実験における冷却速度の増加に よるへマタイト収率の向上は, 冷却速度を $10^{\circ} \mathrm{C} / \mathrm{min}$ に増すと過 冷が起こり, $\mathrm{Na}_{2} \mathrm{~B}_{4} \mathrm{O}_{7}-\mathrm{Fe}_{2} \mathrm{O}_{3}$ 系の共晶濃度が $\mathrm{Na}_{2} \mathrm{~B}_{4} \mathrm{O}_{7}$ 側に移 り溶融へマタイトが過飽和状態で低温まで持ち込まれたのち晶出 するためと考えられる。

冷却速度の収率増大の効果は高純度化処理時間の短縮にとって も好都合である。また $\mathrm{NaF}$ 添加による收率の向上は $\mathrm{Na}_{2} \mathrm{~B}_{4} \mathrm{O}_{7}-$ $\mathrm{NaF}-\mathrm{Fe}_{2} \mathrm{O}_{3}$ 系状態図に関係すると考えられるが，確証は得てい ない。

以上のように, $\mathrm{Na}_{2} \mathrm{~B}_{4} \mathrm{O}_{7}$ 系フラックス溶融法によって, 残渣酸 化鉄の高純度化と收率の向上が可能であることを認めたが, As 含 有量が $30 \mathrm{ppm}$ とまだ高く, それを低くするためや, さらに収率を 高めるための実験方法の検討, たとえば適正なフラックス組成や フラックス一酸化鉄状態図の作成が今後の研究課題と考え, 現在 実験中である。

\section{4. 結 論}

各種鉄鉱石から高純度へマタイトを製造する研究の一環として, まず亜鉛製錬の浸出残渣の脱鉄処理（へマタイト法）で得られる 酸化鉄を対象に, その高純度化を $\mathrm{Na}_{2} \mathrm{~B}_{4} \mathrm{O}_{7}$ フラックス溶融法を用 いて $1,200{ }^{\circ} \mathrm{C}$ の処理温度で行った。そして晶出へマタイト結晶の 大きさ, 純度および収率に及ぼす溶融温度における保持時間, 冷 却速度，酸化鉄/フラックス比, $\mathrm{CuO}$ および $\mathrm{NaF}$ 添加の影響を 調べ，次のような結果が得られたので以下に報告する。

1) へマタイト結晶粒度は $0.1 \sim 4 \mathrm{~mm}$ 程度の薄片であり, 冷却 速度を高めることによって細かくなる。

2) へマタイト結晶の純度はCuO添加の場合を除いて, およそ 99.8\%以上であり, $\mathrm{Zn}, \mathrm{S}$ およびAsの含有量はそれぞれ 200〜 $300 \mathrm{ppm}, 7 \sim 20 \mathrm{ppm}, 30 \mathrm{ppm}$ であった。

3）へマタイト結晶の収率は冷却速度, 酸化鉄 / フラックス比 を増し，かつNaFの添加によって，およそ80\%以上に高めること ができる。

終わりに，本研究を行うにあたり酸化鉄結晶の成分分析で多大 の援助を賜った太平洋金属(株)ならびに秋田製錬(株)の関係諸氏， ならびに実験遂行にご協力いただいた当時学生の杉浦章夫, 中静 金市, 清水 忠各学士の諸氏に謝意を表する。なお本研究の経費 の一部は平成元年度科学研究費補助金によったことを付記して謝 意を表する。

\section{参 考 文 献}

1) 戸田浩次 : 粉体および粉末冶金, 26[7]，235～243，(1979）

2）野村武史：粉体および粉末治金，26[7]，244～249，(1979）

3）工藤節子 · 水渡英明 : 鉄と鋼, $76[4], 515 \sim 522,(1990)$

4) Tasaki, A. and Iida, S.: J Phys. Soc. Japan, 18, $1148 \sim 1163$, (1963)

5) BARKS, R. E. and ROY, D. M. : Crystal Growth, ed. by H. S. PEISER, 497 505, (1967) 